\title{
Aplikasi Akademik Berbasis SMS Gateway Pada SMP XYZ
}

\author{
Yosianus Robertus Isak \\ Program Studi Teknik Informatika STMIK Buddhi \\ Jl. Imam Bonjol No. 41 Karawaci Ilir, Tangerang 15115 \\ yosianusrobertusisak@gmail.com
}

\begin{abstract}
Short Message Service ( SMS ) is a service that widely applied in wireless communication system, allowing for delivery in the form of alphanumeric messages between customer terminals or between terminals customers with external systems such as email, voice mail, and so on . SMS -based service has been used for many years, the penetration of mobile phones and many users are using other services have made SMS-based service into an attractive service. Now the service automation is used to communicate briefly with students or their parents briefly in the school . SMP XYZ is a Junior High School, which is one of the few schools that continue to improve services to students academically both facilities and policies . Based mobile applications are expected to provide a more comfortable facility for students to undertake learning in school . Up to this time if they want to see the value of the subject matter, students or parents are always required to come to school. It would be far better to make the system more flexible so the they can see the value easily without the hassle of coming to school. SMS application server in SMP XYZ is expected to help students and parents who can not attend to school because of the limitations of distance and time to be able to see the value of academic students through mobile media . and the schools can provide the information to students without having to visit the school and disseminate information to students in a school environment
\end{abstract}

Keywords- SMS Gateway, Java, My SQL, SMP XYZ

\section{Pendahuluan}

Perkembangan teknologi telekomunikasi selular berawal dari keinginan orang untuk dapat berkomunikasi tanpa harus terpaku pada suatu tempat saja melainkan dapat bergerak bebas sesuai dengan keinginan orang tersebut. Salah satu dari bagian itu adalah berupa pesan singkat yang biasa disebut SMS (Short Messaging Service). SMS merupakan salah satu fitur GSM yang di kembangkan dan distandarisasi oleh ETSI yaitu badan standar telekomunikasi Eropa yang menstandarisasikan SMS dan fitur-fitur GSM lainnya. Seperti halnya teknologi lain, meluasnya penggunaan SMS juga munculnya aplikasi dan model penggunaan baru. Penggunaan SMS pada saat ini sangat banyak digunakan oleh pengguna telepon seluler, hal ini dikarenakan biaya yang sangat murah dan kegagalan penerimanya sangat kecil.

Aplikasi tersebut berkembang secara pesat beberapa tahun terakhir, sehingga fasilitas SMS ini menjadi nilai tambah dalam rangka kemajuan dunia pendidikan. Namun pada kenyataannya sistem penyampaian informasi di sekolah SMP XYZ masih bersifat manual. Hal ini menyebabkan komunikasi antar sekolah terhambat dan komunikasi antar sekolah dengan orang tua murid kurang efektif. Misalnya untuk siswa-siswinya SMP XYZ masih menggunakan papan pengumuman sebagai sarana informasi, sedangkan untuk menginformasikan kepada orang tua murid, pihak sekolah SMP XYZ mengirim pesan dalam bentuk surat yang dititipkan pada siswa-siswinya.

Namun faktanya yang terjadi selama ini adalah informasi yang dipajang dipapan pengumuman jarang sekali dibaca, sehingga para siswa-siswi SMP XYZ tidak mengetahui informasi yang disampaikan oleh pihak sekolah. Bagi siswasiswi yang tidak sekolah pada waktu itu juga tidak bisa menerima informasi apa yg disampaikan oleh SMP XYZ .

\section{LANDASAN TEORI}

\section{A. Definisi Sistem}

Dewasa ini penggunaan kata sistem semakin meluas dan meliputi berbagai bidang, sehingga timbul berbagai definisi dan istilah tentang sistem tersebut yang masingmasing beranjak dari sudut pandang dan lingkup pengertian itu sendiri. Pada dasarnya kata sistem berasal dari bahasa Yunani "Sytema" yang berarti kesatuan, yakni keseluruhan dari bagian-bagian yang mempunyai hubungan satu sama lain. Teori tentang sistem menurut beberapa pakar adalah sebagai berikut : Sistem adalah suatu jaringan kerja dari prosedurprosedur yang saling berhubungan, berkumpul bersama-sama untuk melakukan suatu kegiatan atau untuk menyelesaikan suatu sasaran yang tertentu.

\section{B. Definisi UML}

UML (Unfied Modelling Language) adalah salah satu alat bantu yang handal di dunia pengembangan sistem yang berorientasi obyek. Hal ini disebabkan karena UML menyediakan bahasa pemodelan visual yang memungkinkan bagi pengembangan sistem untuk membuat cetak biru atas visi mereka dalam bentuk yang baku, mudah dimengerti serta di lengkapi dengan mekanisme yang efektif untuk berbagi (sharing) dan mengkomunikasikan rancangan mereka dengan yang lain. 
Dengan UML, metode Booch, OMT dan OOSE digabungkan dengn elemen-elemen yang tidak praktis ditamabah dengan elemen-elemen yang tidak praktis di tambah dengan elemen-elemen lain yang efektif dan elemenelemen baru yang belum ada pada metode terdahulu sehingga UML lebih eksperesif dan serangan daripada metode lainya. Gambar dari unsur-unsur yang membentuk UML.

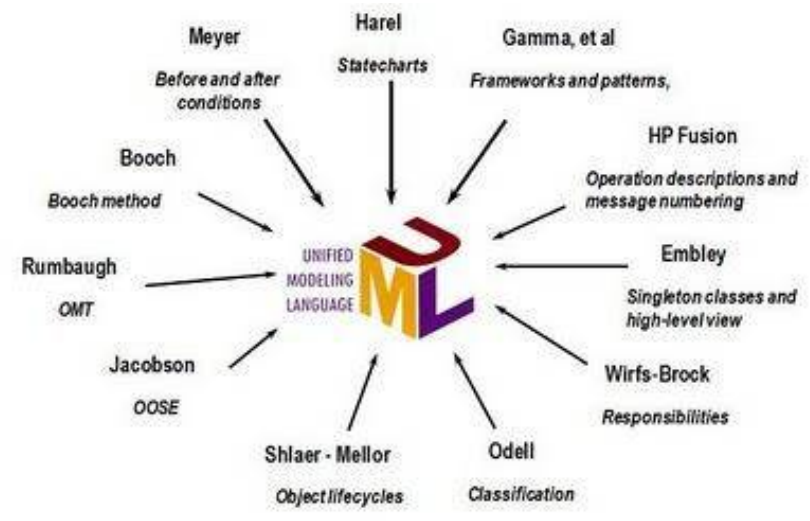

Gambar 1. Unsur-unsur pembentuk UML (Graha Ilmu 2005:18).

UML menyediakan 10 macam diagram untuk memodelkan aplikasi berorientasi objek, yaitu:

Use Case Diagram untuk memodelkan proses bisnis.

1) Conceptual Diagram untuk memodelkan konsepkonsep yang ada di dalam aplikasi.

2) Sequence Diagram untuk memodelkan pengiriman pesan (message) antar objek.

3) Collaboration Diagram untuk memodelkan interaksi antar objek.

4) State Diagram untuk memodelkan perilaku objek di dalam sistem.

5) Activity Diagram untuk memodelkan perilaku user dan objek di dalam sistem.

6) Class Diagram untuk memodelkan struktur kelas.

7) Objek Diagram untuk memodelkan struktur objek.

8) Component Diagram untuk memodelkan komponen objek.

9) Deployment Diagram untuk memodelkan distribusi aplikasi.

\section{Perintah AT Command}

Dibalik teks SMS yang diterima dan dikirim pada sebuah telepon seluler sebenarnya adalah berupa perintah AT Command yang bertugas mengirim atau menerima data dari dan ke SMS Center.
Tabel 1. Perintah AT Command

\begin{tabular}{|l|l|}
\hline Perintah AT & Kegunaan \\
\hline AT & $\begin{array}{l}\text { Mengecek apakah handphone } \\
\text { telah terhubung }\end{array}$ \\
\hline AT+CMGF & $\begin{array}{l}\text { Menetapkan format mode dari } \\
\text { Terminal }\end{array}$ \\
\hline AT+CSCS & Menetapkan jenis encoding \\
\hline AT+CNMI & $\begin{array}{l}\text { Mendeteksi pesan SMS baru } \\
\text { masuk secara otomatis }\end{array}$ \\
\hline AT+CMGL & $\begin{array}{l}\text { Membuka daftar SMS yang } \\
\text { ada pada SIM Card }\end{array}$ \\
\hline AT+CMGS & Mengirim Pesan SMS \\
\hline AT+CMGR & Membaca Pesan SMS \\
\hline AT+CMGD & Menghapus Pesan SMS \\
\hline
\end{tabular}

\section{ERD (Entity Relationship Diagram)}

ERD (Entity Relationship Diagram) adalah pemodelan data utama yang membantu mengorganisasikan data dalam suatu proyek ke dalam entitas-entitas dan menentukan hubungan antar entitas.

ERD sendiri erat hubungannya dalam dunia manajemen basis data, merupakan suatu rancangan menjadi salah satu kunci untuk menentukan menajemen tabel untuk terciptanya sebuah tabel yang normal dan seefisien mungkin serta terbebas dari ambiguity (memiliki atribut yang kembar) dari suatu kasus. Beberapa istilah dalam perancangan tabel :

\section{1) Entitas}

Entitas merupakan objek yang mewakili sesuatu yang nyata dan dapat dibedakan dari sesuatu yang lain (Fathansyah, 1999: 30).

\section{2) Atribut}

Atribut adalah properti atau karakteristik yang dimiliki oleh suatu entitas dimana properti atau karakteristik itu bermakna atau berarti bagi organisasi atau perusahaan, misalnya untuk pencatatan data pegawai di suatu instansi, entitas pegawai mungkin memiliki atribut-atribut nomor induk pegawai, nama, alamat, nomor telepon, gaji pokok dan lainnya. Setiap diagram hubungan entitas bisa terdapat lebih dari satu atribut.

\section{3) Hubungan Relasi/Kardinalitas}

Hubungan antara sejumlah entitas yang berasal dari himpunan entitas yang berbeda. Relasi yang terjadi diantara dua himpunan entitas (misalnya A dan B) dalam satu basis data yaitu (Abdul Kadir, 2002: 48) :

One to one (satu ke satu).

Hubungan relasi satu ke satu yaitu setiap entitas pada himpunan entitas A berhubungan paling banyak dengan satu entitas pada himpunan entitas B.

One to many (satu ke banyak). 
Setiap entitas pada himpunan entitas A dapat berhubungan dengan banyak entitas pada himpunan entitas B, tetapi setiap entitas pada entitas B dapat berhubungan dengan satu entitas pada himpunan entitas A.

\section{Many to many (banyak ke banyak).}

Setiap entitas pada himpunan entitas A dapat berhubungan dengan banyak entitas pada himpunan entitas B.

\begin{tabular}{|c|c|}
\hline Notasi & Keterangan \\
\hline Eritax & $\begin{array}{l}\text { Entitas, adalah suatu objek yang dapat diidentifikasi } \\
\text { dalam lingkungan pemakai. }\end{array}$ \\
\hline & $\begin{array}{l}\text { Relasi, menunjukkan adanya hubungan di antara } \\
\text { sejumlah entitas yang berbeda. }\end{array}$ \\
\hline Arovut & $\begin{array}{l}\text { Atribut, berfungsi mendeskripsikan karakter entitas } \\
\text { (atribut yg berfungsi sebagai key diberi garis bawah) }\end{array}$ \\
\hline & $\begin{array}{l}\text { Garis, sebagai penghubung antara relasi dengan } \\
\text { entitas, relasi dan entitas dengan atribut. }\end{array}$ \\
\hline
\end{tabular}

Gambar 2. Tabel Komponen ERD

\section{E. Perangkat Lunak yang Digunakan}

Perangkat lunak yang digunakan dalam tahapan membangun aplikasi pengecekan Nilai berbasis SMS Gateway untuk pelayanan informasi akademik murid adalah sebagai berikut.

\section{F. Java Programming}

Java adalah bahasa pemrograman yang berorientasi objek (Object Oriented Programming) dan dapat dijalankan pada beberapa platform sistem operasi. Perkembangan Java tidak hanya berfokus pada satu sistem operasi, tetapi dikembangkan untuk berbagai sistem operasi dan bersifat open source. Ide dasar pada bahasa berorientasi objek adalah mengkombinasikan data dan fungsi untuk mengakses data menjadi sebuah kesatuan unit. Unit ini dikenal dengan objek (object). Object sebenarnya mencerminkan pola manusia dengan dalam kehidupan sehari-hari. Tiga karakteristik utama dari bahasa yang berorientasi adalah Encapsulation, Inheritance, dan polymorphism. Encapsulation adalah bungkusan pelindung program dan data yang sedang diolah. Inheritance merupakan sifat dalam bahasa orientasi objek yang memungkinkan sifat-sifat dari suatu class utama diturunkan ke subclass. Polymorphism adalah konsep sederhana yang memperolehkan method memiliki beberapa implementasi. Lingkungan pengembagan Java ada dua bagian, yaitu Java Compiler dan Java Interpreter. Compiler membangkitkan bytecode (sekumpulan instruksi yang melakukan resemble kode mesin tetapi tidak spesifik pada prosesor ). Selain itu, ada kode mesin dan interpreter yang mengeksekusi program Java. Kekurangan menggunakan bytecode ialah kecepatan eksekusi. Untuk menulis program
Java, dibutuhkan editor, compiler Java dan Java Runtime Environment.

Java bukan hanya sekedar bahasa pemrograman, tetapi merupakan platform. Banyak bahasa pemrograman yang tidak memiliki fitur seperti multithreading, GUIbuilding, dan kemampuan dalam networking, dimana harus menggunakan hardware atau operating-sistem dependent API ( Application Program Interface) pada teknologi pertama yang berintegrasi penuh untuk dapat menggunakan thread, socket, GUI component dan masih banyak lagi.

Saat ini Java telah mencapai versi 1.5. Pada saat Java mencapai versi 1.2, versi ini telah dikenal dengan nama Java2. Aplikasi-aplikasi Java yang kompatibel dengan Java 2 ini dikenal dengan Java 2 Compliant. Pada Java 2 ini, dibagi menjadi tiga katagori, yaitu:

\section{1) Java 2 Standard Edition ( J2SE )}

Kategori ini digunakan untuk menjalankan dan mengembangkan aplikasi-aplikasi Java pada level PC (Personal Komputer).

\section{2) Java 2 Enterprise Edition ( J2EE)}

Kategori ini digunakan untuk menjalankan dan mengembangkan aplikasi-aplikasi Java pada lingkungan enterprise, dengan menambahkan fungsi-fungsi Java seperti EJB ( Enterprise Java Bean), Java COBRA, servlet dan JSP, serta Java XML (Extensible Markup Language).

\section{3) Java 2 Micro Edition (J2ME)}

Kategori ini digunakan untuk menjalankan dan mengembangkan aplikasi-aplikasi Java pada handheld device atau perangkat-perangkat seperti handphone, palm, PDA, dan pocket PC.

\section{G. $M y S Q L$}

MySQL adalah software sistem manajemen database Database Management Sistem (DBMS) yang sangat populer dikalangan pemrogaman web,terutama dilingkungan Linux dengan script PHP dan perl. Software database ini kini telah tersedia juga dalam platform sistem operasi windows. MySQL merupakan database yang paling populer digunakan untuk membangun aplikasi web yang menggunakan database sebagai sumber dan pengelola datanya. MySQL merupakan database yang digunakan oleh situs-situs terkemuka di Internet untuk menyimpan datanya.

Kepopuleran MySQL dimungkinkan karena kemudahannya untuk digunakan, cepat secara kinerja query, dan mencukupi untuk kebutuhan database perusahaan-perusahaan skala menengah kecil. MySQL merupakan database yang digunakan situs-situs terkemuka di Internet untuk menyimpan datanya. Software database MySQL kini dilepas sebagai software manajemen database yang open source, sebelumnya merupakan merupakan database yang shareware. Shareware adalah suatu software yang dapat di distribusikan secara bebas untuk keperluan penggunaan secara pribadi, tetapi jika digunakan secara komersial maka pemakai harus mempunyai lisensi dari 
pembuatnya. Software open source menjadikan software dapat didistribusikan secara bebas dan dapat dipergunakan untuk keperluan pribadi atau pun komersial, termasuk didalamnya source code dari software tersebut. Database MySQL tersedia secara bebas dan cuma-cuma dan boleh digunakan oleh setiap orang, dengan lisensi open source GNU

GeneralPublic License (GPL) ataupun lisensi komersial non GPL.

\section{H. Netbeans}

NetBeans mengacu pada dua hal, yakni platform untuk pengembangan aplikasi desktop java, dan sebuah Integrated Development Environment (IDE) yang dibangun Menggunakan platform NetBeans. Platform Netbeans memungkinkan aplikasi dibangun dari sekumpulan komponen perangkat lunak moduler yang disebut "modul". Sebuah modul adalah suatu arsip Java (Java archive) yang memuat kelas-kelas Java untuk berinetraksi dengan NetBeans Open API dan file manifestasi yang mengidentifikasinya sebagai modul.

Aplikasi yang dibangun dengan modul-modul dapat dikembangkan dengan menambahkan modul-modul baru. Karena modul dapat dikembangkan secara independen, aplikasi berbasis platform NetBeans dapat dengan mudah dikembangkan oleh pihak ketiga. Secara mudah dan powerfull. Netbeans IDE adalah IDE open source yang ditulis sepenuhnya dengan bahasa pemrograman Java menggunakan platform Netbeans. Netbeans IDE mendukung pengembangan semua tipe aplikasi Java(J2SE, web, EJB, dan Aplikasi Mobile). Fitur lainnya adalah sistem proyek berbasis Ant, kontrol versi, dan refactoring.

Versi terbaru saat ini adalah Netbeans IDE 6.7.1 yang dirilis Oktober 2009 mengembangkan fitur-fitur Java EE yang sudah ada(termasuk Java Persistence support, EJB-3 dan JAX-WS). Sementara paket tambahannya, NetBeans Enterprise Pack mendukung pengembangan aplikasi perusahaan Java EE 5, meliputi alat desain visual SOA, skema XML, web service dan pemodelan UML. NetBeans $\mathrm{C} / \mathrm{C}++$ Pack Mendukung proyek $\mathrm{C} / \mathrm{C}++$. Modularitas semua fungsi IDE disediakan oleh modul-modul.

Tiap modul menyediakan fungsi yang didefenesikan dengan baik,seperti dukungan untuk bahasa pemrograman Java, editing, atau dukungan bagi CVS. NetBeans memuat semua modul yang diperlukan dalam pengembangan Java dalam sekali download, memungkinkan pengguna untuk mulai bekerja sesegera mungkin. Modulmodul juga mengijinkan NetBeans untuk bisa dikembangkan.

Fitur-fitur baru, seperti dukungan untuk bahasa pemrograman lain, dapat ditambahkan dengan menginstal modul tambahan. Sebagai contoh, Sun Studio, Sun Java Studio Enterprise, dan Sun Java Studio Creator dari Sun Microsistem semuanya berbasis NetBeansIDE.

\section{I. $X A M P P$}

Fungsinya adalah sebagai server yang berdiri sendiri (localhost), yang terdiri atas program Apache HTTP
Server, MySQL database, dan penerjemah bahasa yang ditulis dengan bahasa pemrograman PHP dan Perl. Nama XAMPP merupakan singkatan dari X (empat sistem operasi apapun), Apache, MySQL, PHP dan Perl. Program ini tersedia dalam GNU General Public License dan bebas, merupakan web server yang mudah digunakan yang dapat melayani tampilan halaman web yang dinamis.

\section{J. SMS (Short Message Service)}

Short Message Service (SMS) merupakan sebuah layanan yang banyak diaplikasikan pada sistem komunikasi tanpa kabel, memungkinkan dilakukannya pengiriman pesan dalam bentuk teks. SMS didukung oleh GSM (Global Sistem For Mobile Communication), TDMA (Time Division Multiple Access), CDMA (Code Division Multiple Access) yang berbasis pada telepon seluler yang saat ini banyak digunakan.

\section{K. Cara Kerja SMS}

Dalam sistem SMS, mekanisme utama yang dilakukan dalam suatu sistem adalah melakukan pengiriman short message dari satu terminal customer ke terminal yang lain. Hal ini dapat dilakukan berkat adanya sebuah entitas dalam sistem SMS yang bernama Short Message Service Center (SMSC), disebut juga Message Center (MC). Pada saat pesan SMS dikirim dari handphone (mobile orginated) pesan tersebut tidak langsung dikirim ke handphone tujuan (mobile terminated), akan tetapi terlebih dahulu ke SMSC, baru kemudian pesan tersebut dikirimkan ke handphone tujuan.

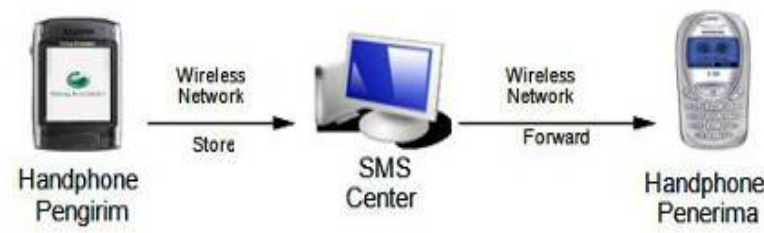

Gambar 3. Cara Kerja SMS

\section{Metode Penelitian}

\section{A. Metodologi Penelitian}

Sebelum dilakukan pengembangan system telah dilakukan penelitian pengumpulan data dan pengembangan perangkat lunak.

\section{B. Pengumpulan Data}

Dalam penulisan ini, digunakan beberapa metode untuk dapat melakukan pengumpulan data yaitu:

1) Metode studi pustaka.

Mempelajari buku-buku yang menunjang dan mencari informasi yang berhubungan dengan SMS Gateway, serta menggunakan media internet untuk mencari situs-situs 
yang berhubungan serta menunjang informasi yang berkaitan dengan SMS Gateway.

\section{2) Metode wawancara}

untuk mengetahui permasalahan yang dihadapi dan mendiskusikan aplikasi yang diharapkan dapat memecahkan permasalahan tersebut, maka penulis melakukan metode wawancara dengan pihak kepala sekolah, guru, dan tata usaha yang melakukan pengolahan data siswa serta beberapa siswa di SMP XYZ .

3) Metode pengamatan Lapangan

Penulis secara langsung melakukan pengamatan kepada pihak yang berkaitan dengan sistem untuk memperoleh data agar lebih lengkap.

\section{Pengembangan Perangkat Lunak}

Metodelogi pengembangan perangkat lunak yang digunakan adalah OOSE (Object Oriented Sofware Engenering). Dalam OOSE, perancangan diimplementasikan dalam use case dan block. Use case adalah kasus penggunaan perangkat lunak yang mungkin dilakukan oleh sistem luar atau user atau kalau dalam OOSE disebut sebagai aktor. Rancangan dan mekanisme yang akan dibuat pada aplikasi SMS Gateway berbasis Akademik Pada SMP XYZ ini dibangun menggunakan UML (Unified Modeling Language).

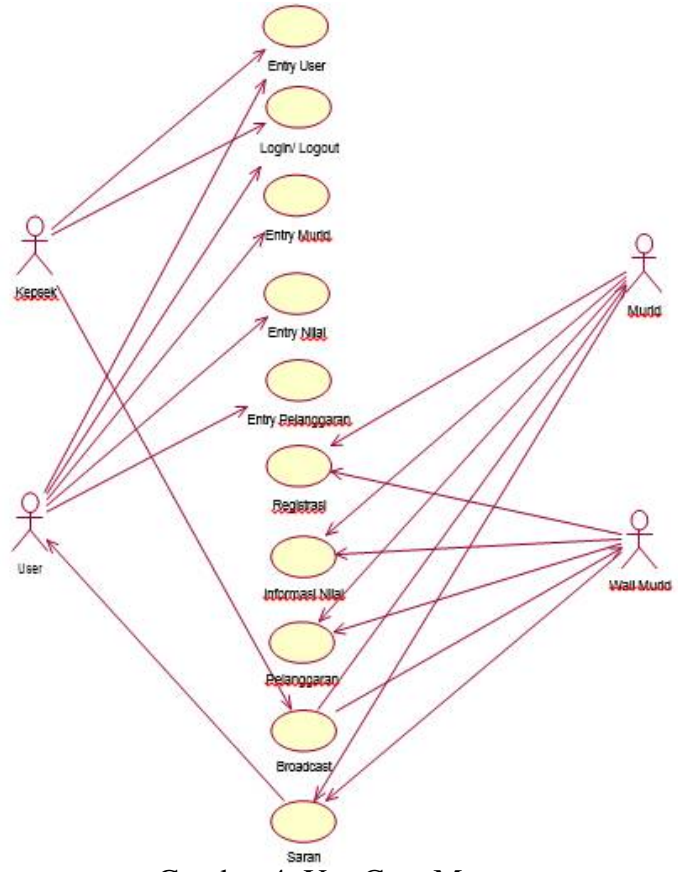

Gambar 4. Use Case Master

\section{Entity Relationship Diagram (ERD)}

Digunakan untuk menyatakan jenis data dari hubungan yang diantara jenis data yang terdapat pada sistem. Tujuan pemodelan ERD adalah menunjukkan hubungan simpanan data dan menghilangkan kerangka data serta membuat model yang dapat dimengerti dengan baik oleh pemakai maupun personal komputer.

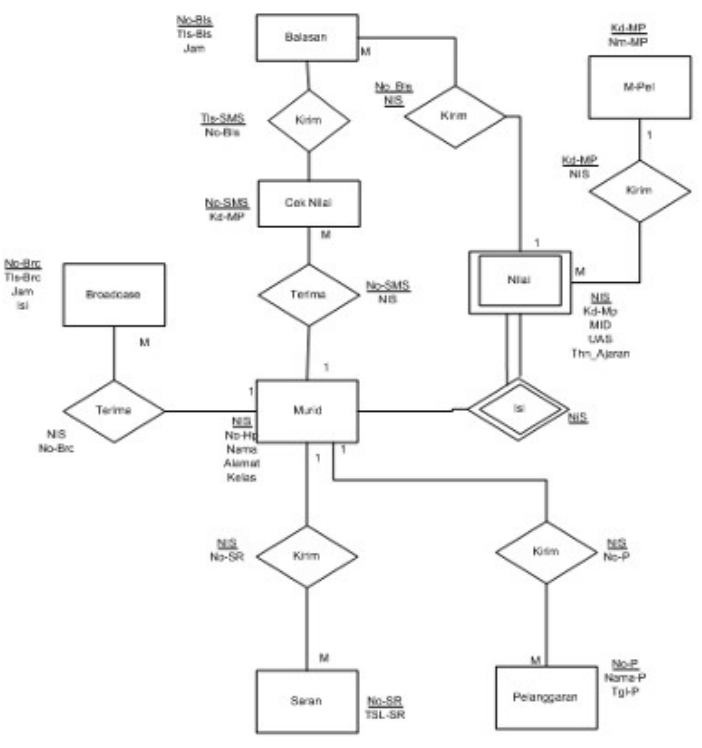

Gambar 5. ERD

\section{E. Transformasi ERD ke LRS (Logical Record Structure)}

Transformasi diagram ER ke Logial Record Structure(LRS)Merupakan kegiatan membentuk dara dari diagram ER ke dalam LRS. Gambar transformasi diagram ER ke Logical Record Structure akan digambar sebagai berikut :

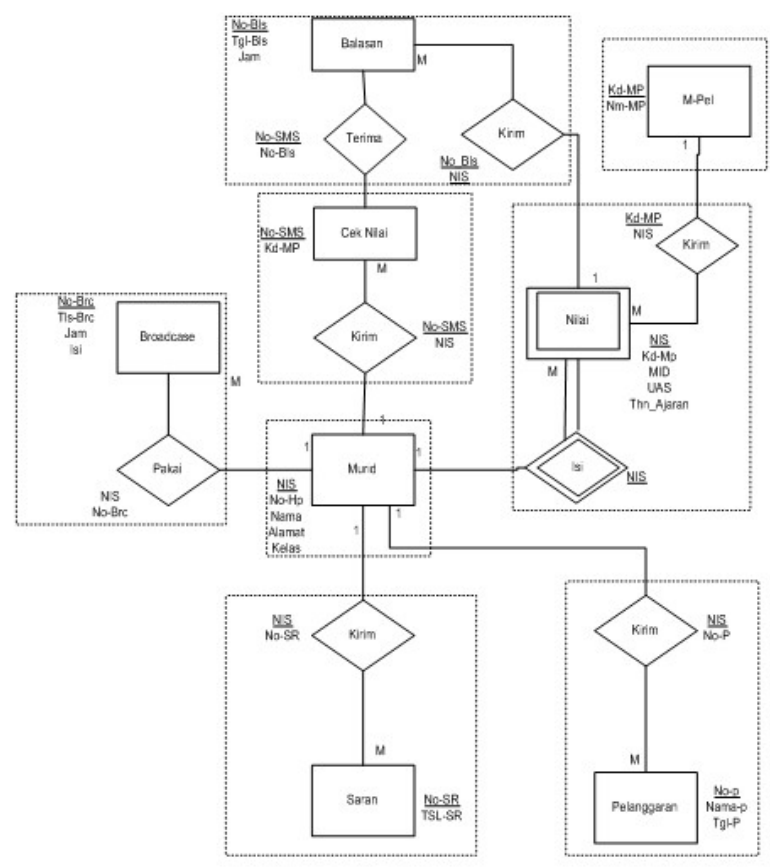

Gambar 6. Transformasi ERD ke LRS 


\section{HASIL DAN PEMBAHASAN}

\section{A. Tampilan Layar Form User}

Pada Form User terdapat User, Kata Sandi, Nama, Nomor Telepon, dan Alamat. Pada form ini juga terdapat tombol tambah, simpan, ubah, hapus, tutup. Tombol simpan,ubah,hapus tidak aktif apabila admin masih kosong.

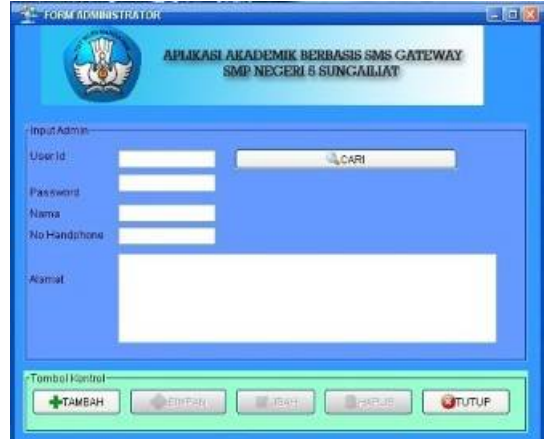

Gambar 7. Tampilan Form User

\section{B. Tampilan Layar Form Login}

Pada tampilan layar Form user ini terdapat Pengguna Server dan password. Tombol login untuk memproses pengecekan pengguna server dan password.

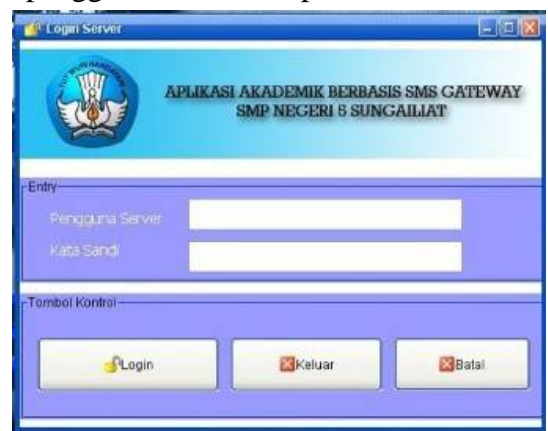

Gambar 8. Tampilan Form Login

\section{Tampilan Layar Menu Utama}

Tampilan Layar menu utama adalah tampilan awal pada aplikasi ini, Pada menu utama terdapat empat menu pilihan, yaitu File Sekolah, File Master SMP XYZ , SMS Server Broadcast, About.

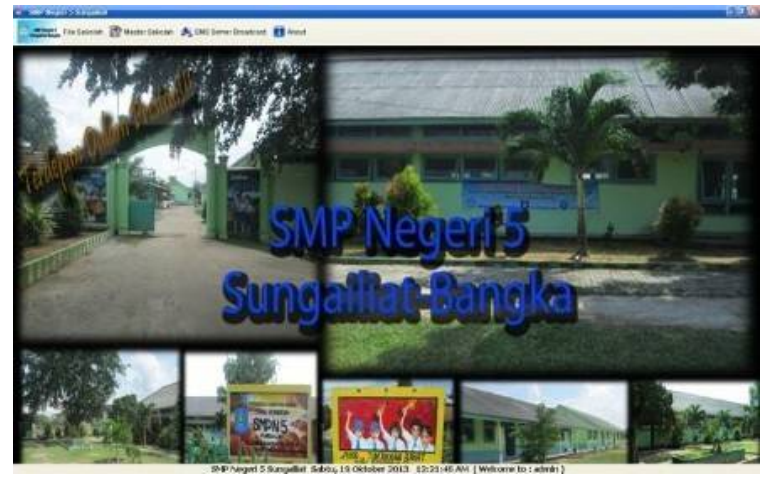

Gambar 9. Tampilan Form Menu Utama

\section{Tampilan Layar Form Data Siswa}

Pada Tampilan Form murid ini terdapat Nomor Handpone, Nama Murid, NIS, dan Alamat.

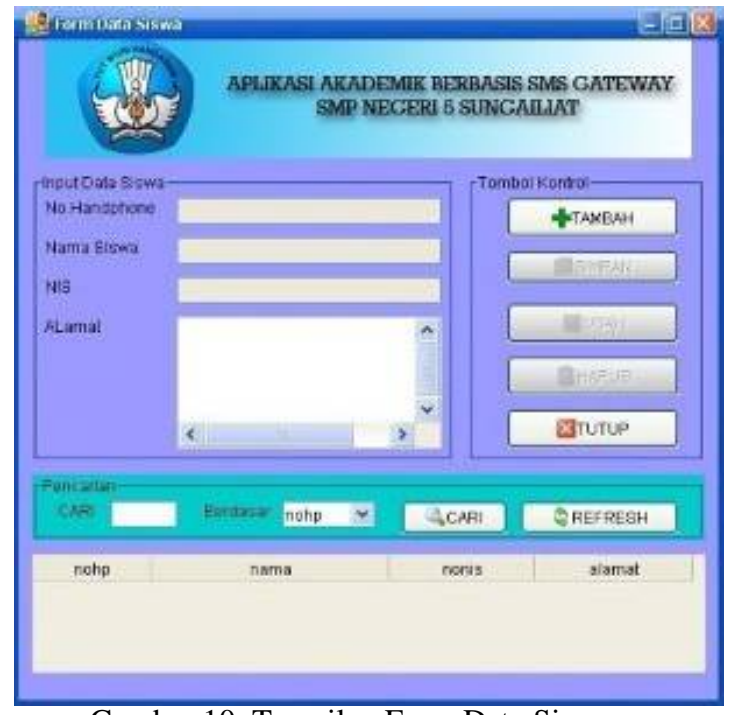

Gambar 10. Tampilan Form Data Siswa

\section{E. Tampilan Layar Form Nilai}

Pada form nilai terdapat NIS, Nama, Matpel, Nilai UTS, dan Nilai UAS. Pada Form ini juga terdapat tombol tambah, simpan, ubah, hapus, dan tutup.

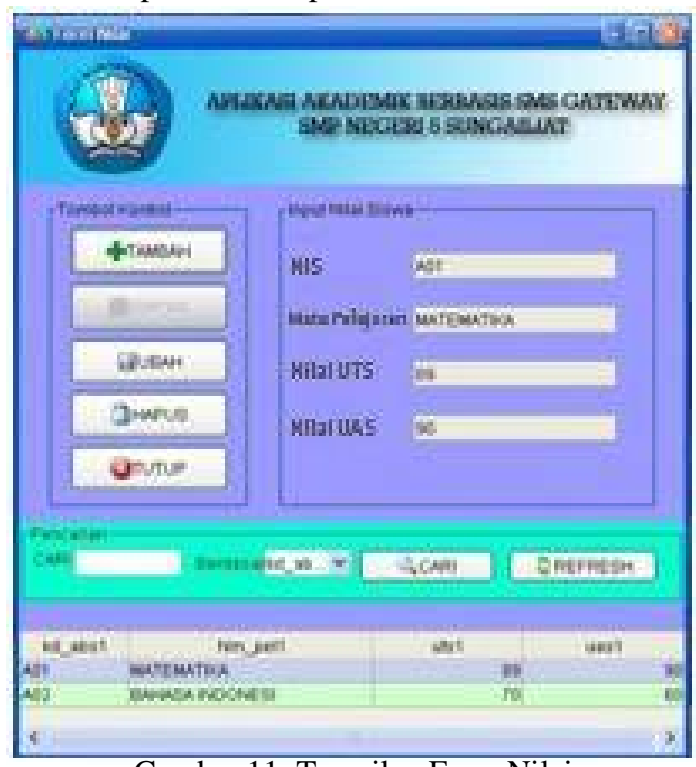

Gambar 11. Tampilan Form Nilai

\section{F. Tampilan Layar Form Pelanggaran}

Pada Form Admin terdapat NIS dan Pelanggaran. Pada form ini juga terdapat tombol tambah, simpan, ubah, hapus, dan tutup. 


\section{G. Tampilan Layar Form Kepala Sekolah}

Pada tampilan form kepala sekolah ini terdapat Nama Kepala Sekolah, Nomor Handphone.

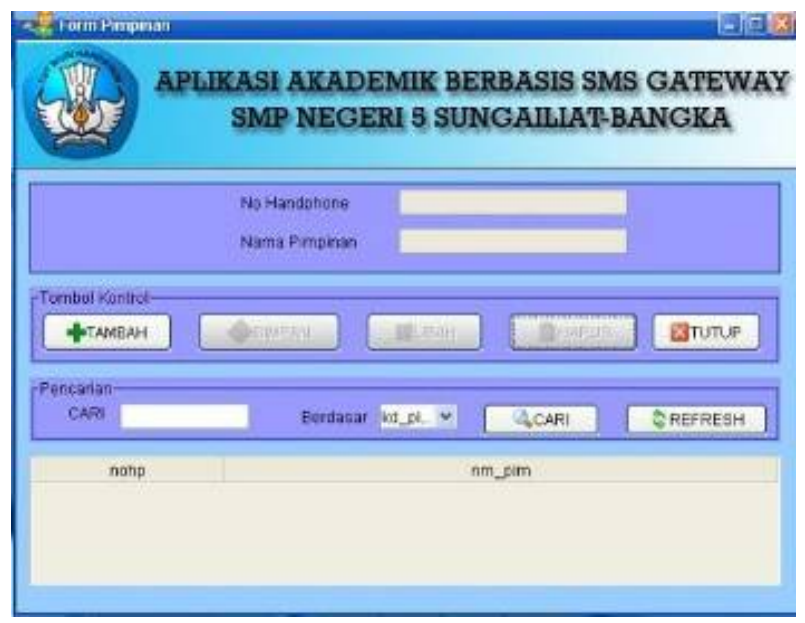

Gambar 12. Tampilan Form Kepala Sekolah

\section{H. Tampilan Layar Form SMS Server}

Pada Form SMS Server ini terdapat Port, Kecepatan Transfer, Tabel sms masuk, Tabel sms terkirim, Tabel saran, data broadcast.

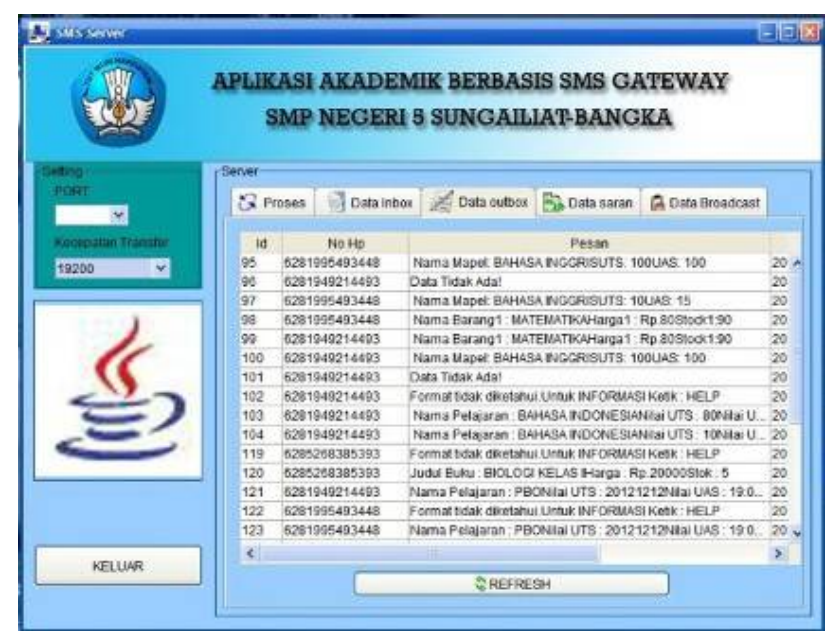

Gambar 13. Tampilan Layar Form SMS Server

\section{Format SMS}

Dengan adanya sistem ini diharapkan proses pengolahan informasi yang dibutuhkan siswa dan orang tua siswa akan dapat langsung diproses dan langsung dikirm sesuai tujuan saat itu juga. Begitu pula dengan informasi yang akan diberikan kepada siswa atau orang tua siswa akan dapat langsung dikirim ke handphone-nya, sehingga informasi yang dikirim tepat sasaran dengan waktu yang cepat.
Tabel 2. Format SMS

\begin{tabular}{|l|l|}
\hline Format SMS & Keterangan \\
\hline $\begin{array}{l}\text { Reg } \\
<\text { Spasi }>\text { Nama\#Nis\#Alamat }\end{array}$ & $\begin{array}{l}\text { Untuk melakukan registrasi } \\
\text { nomor hp siswa dan orang tua }\end{array}$ \\
\hline UNREG & $\begin{array}{l}\text { Untuk keluar dari system } \\
\text { SMS Gateway }\end{array}$ \\
\hline LGR8A<spasi>NIS & $\begin{array}{l}\text { Untuk melihat pelanggaran } \\
\text { yang pernah dilakukan }\end{array}$ \\
\hline BIND8A<spasi>NIS & $\begin{array}{l}\text { Untuk melihat nilai } \\
\text { matematika }\end{array}$ \\
\hline HELP & $\begin{array}{l}\text { Untuk melihat semua request } \\
\text { yang ada pada SMS Gateway }\end{array}$ \\
\hline SARAN & $\begin{array}{l}\text { Untuk memberikan saran } \\
\text { kepada sekolah }\end{array}$ \\
\hline
\end{tabular}

J. Tampilan Balasan yang Dikirim SERVER pada Handphone Penerima

Berikut ini adalah tampilan semua Format SMS untuk setiap request yang dikirimkan oleh Murid dan Wali Murid.

1) Request REG

Request "REG" berfungsi untuk melakukan Registrasi agar bisa menggunakan fasilitas request, aplikasi membalasnya dengan pesan SMS yang berbeda untuk Murid dan Wali Murid.

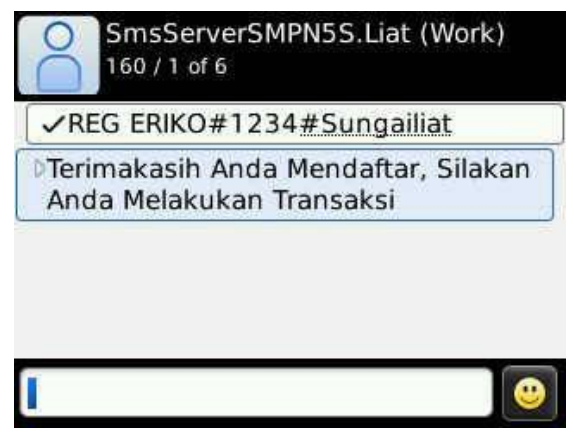

Gambar 14. Tampilan Balasan Request REG

\section{2) Request UNREG}

Request "UNREG" berfungsi untuk keluar dari database aplikasi sehinggga Murid dan Wali Murid tidak bisa lagi menggunakan fasilitas request.

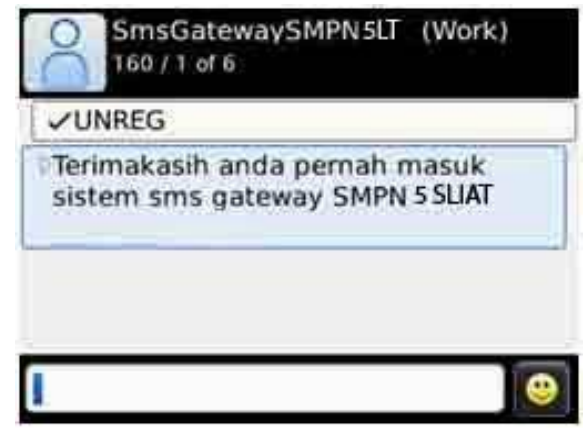

Gambar 15. Tampilan Balasan Request UNREG 
3) Request Pelanggaran

Request "LGR8A<spasi>NIS" berfungsi untuk mengetahui pelanggaran apa saja yang dilakukan oleh Murid di sekolah, aplikasi membalasnya dengan pesan yang berbeda untuk Murid dan Wali Murid.

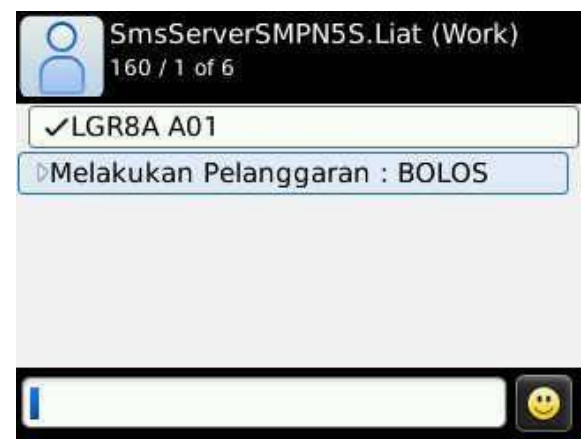

Gambar 16. Tampilan Request Pelanggaran

\section{4) Request Nilai}

Request "BIND8A<spasi>NIS" berfungsi untuk mengetahui Nilai Matematika. Aplikasi membalasnya dengan Data nilai UTS dan nilai UAS Matematika Murid.

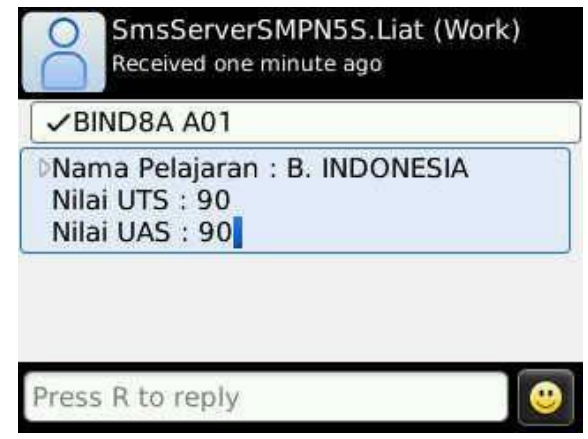

Gambar 17. Tampilan Request Nilai

\section{5) Request HELP}

Request "HELP" untuk mengetahui informasi format SMS, aplikasi akan membalas dengan pesan SMS yang berisi informasi format SMS untuk request.

\begin{tabular}{|l|}
\hline SmsServerSMPN5S. Liat (Work) \\
Sent one minute ago
\end{tabular}

Gambar 18. Tampilan Request HELP

\section{6) Request SARAN}

Request "SARAN<spc>ISI SARAN" berfungsi

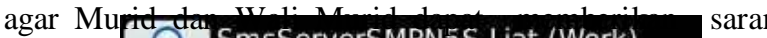
kepada SmsServerSMPN5S.Liat (Work) $160 / 1$ of 6

$\checkmark$ SARAN tambah menu lain

Saran Anda telah kami terima, terima kasih atas saran anda

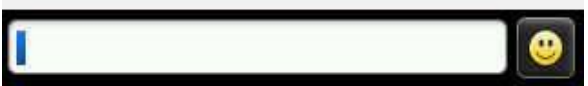

Gambar 19. Tampilan Request Saran

\section{Penutup}

\section{A. Kesimpulan}

Dari hasil analisa terhadap masalah dan aplikasi yang dikembangkan maka dapat ditarik beberapa kesimpulan, antara lain :

- Dengan adanya aplikasi berbasis SMS ini, dapat memudahkan siswa dan Orang tua siswa dalam mendapatkan informasi nilai siswa, pelanggaran yang siswa lakukan didalam sekolah.

- Dengan aplikasi berbasis SMS ini, siswa beserta orang tua siswa mendapatkan informasi lebih efisien dari sekolah karena kita tidak perlu datang ke sekolah tersebut.

- Seorang administrator masih dibutuhkan untuk menjalankan sistem SMS broadcast pada aplikasi ini.

\section{DAFTAR PUSTAKA}

[1] Mulyadi, Sistem Akuntansi . Edisi 2. Yogyakarta : Sekolah Tinggi Ilmu Ekonomi YKPN, 2001.

[2] Jusuf, AL. Haryono. Dasar-Dasar Akuntansi.Edisi 6.Yogyakarta SekolahTinggi Ilmu Ekonomi YKPN, 2002.

[3] Mulyadi. Sistem Akuntasi. Yogyakarta : Sekolah Tinggi ilmu Ekonomi YKPN, 1997.

[4] Purnama Rangsang. 2003. Tuntunan Pemrograman Java Jilid 2. Tim Prestasi Pustaka: Surabaya.

[5] Wahana Komputer. Tim Penelitian dan Pengembangan. 2005 Pengembangan Aplikasi Sistem Informasi Akademik Berbasis SMS dengan JAVA. Edisi Pertama. Salemba Infotek : Jakarta. 